\title{
Reflecting on Early Arthritis
}

"To become a man is to be responsible; to be ashamed of miseries that you did not cause."

$$
\text { - Antoine de Saint-Exupéry }{ }^{1}
$$

I recently returned from a much-anticipated Hawaiian vacation. During the lengthy plane ride, I had time to relax and reflect. I thought about the provocative work by Tavares, et al, showing that only $41 \%$ of patients with rheumatoid arthritis (RA) were started on therapy within 6 months of presumed onset of disease, and that $78 \%$ of the delay was attributable to processes/events that occurred before the patients ever saw a rheumatologist ${ }^{2}$. I thought about the excellent literature review categorizing delays of diagnosis and treatment by time from symptoms to assessment by a primary care physician (PCP), from PCP to rheumatology referral and then assessment, and finally to commencement of disease-modifying antirheumatic drug therapy $^{3}$. I thought about a patient from a few months ago - an otherwise healthy young woman with palindromic arthritis following a sore throat, whose symptoms quickly and fully resolved; I suspected her illness likely viral and transient in nature ${ }^{4}$, even though she had mentioned some prior complaints that were suspicious, but not definitive, for RA. Antibodies to anticitrullinated protein and rheumatoid factor had been measured and were positive. How do I classify and treat this patient? I thought about this patient's relative good fortune in having ready access to expert care in contrast to those, for example, at public institutions where patients may wait as long as 6 to 12 months for rheumatologic evaluation ${ }^{5}$. I thought about other patients with arthritis, both here and throughout the world, who do not even have this care. And I thought about the increasingly documented inequities in rheumatologic and other health care ${ }^{6,7}$.

I thought, too, about our profound progress over the last decade - greater and more efficacious pharmacotherapy, increased use of better indices of disease activity, more specific autoantibody testing, and improved diagnostic and assessment techniques such as magnetic resonance imaging and ultrasonography ${ }^{8,9}$. I recalled that a step-up, tight-control strategy, with monthly visits and computer-assisted management, was superior to usual care for early disease ${ }^{10}$. I thought about how these advances now compel us to think differently about the treatment of patients with early RA. I wondered how aggressive we should be in very early RA, hoping to minimize symptoms, prevent joint damage, and avoid disability, all while avoiding unnecessary toxicity from treatments. I wondered how to identify and reach patients who could benefit from early treatment of arthritis, without disparity or inequity. I wondered about our obligation to these patients beyond simply being available to those who reach us. I thought of Berwick's recent JAMA essay that argued eloquently that we have societal obligations to address this ${ }^{1}$. Was this not similar to the expectation of the Institute of Medicine that health care in this century be timely, economical, safe, patient-centered, efficient, equitable, and effective ? $^{11}$ I too thought that part of our professional and societal, indeed human responsibilities, was to do what we can to assure that all have access to our care ${ }^{12}$. As the plane continued its flight over the ocean, I wondered how such a vision could become a reality. Perhaps it was then that I dozed off.

I awoke from what seemed to be a hazy dream. I conjured a memory of an idyllic, undiscovered, remote island in the Pacific with a population whose healthcare problems were similar to ours. The island contained roughly 500,000 inhabitants and had 8 rheumatologists (about the same ratio of rheumatologists per population as in the United States). There was care for all patients with arthritis. Some of the details of my reverie were imprecise, but this is what I could recall.

The system was predicated on innovative and emerging principles for finding patients, providing access to care in certain novel ways, and managing patients by using evolving technologies. The island society implemented clinical case-finding strategies that included questionnaires and autoantibody testing to identify patients with early inflammatory arthritis ${ }^{3}$. The islanders had an abundance of high-quality website providing aid for early referral. Patients sought medical attention when symptoms affected daily activities ${ }^{13}$.

Easily read signage was everywhere, explaining the concept of RA. Shopping areas, grocery stores, malls, schools, beaches, and pharmacies were particularly targeted. Public service announcements about safe boating practice were replaced in part with spots about arthritis symptoms. The

\section{See Time to DMARD treatment in RA, page 2088}


citizenry understood the signs and symptoms of arthritis and knew they should seek care if and when symptoms occurred. There were booths at public health fairs and elsewhere, widely available, where people could go for confirmation of arthritis symptoms, using ultrasound and video images that were transmitted to remote sites for immediate and expert interpretation; this was followed by an appropriate recommendation or referral based on available algorithms $\mathrm{s}^{3,14,15}$.

Patients with relatively straightforward and uncomplicated problems were followed by specially trained "rheumatology practitioners" including nurses, pharmacists, nurse practitioners, physician assistants, and others. Patients needing more expertise were seen by specially educated PCP with interest and competence in rheumatology; these physicians supervised many of the "rheumatology practitioners" 9,16 . Patients requiring the most attention were seen, educated, and managed by rheumatologists. While some patients were cared for individually, others were treated in groups and in immediate/open access clinics ${ }^{9,17}$, providing patients with a support network and allowing rheumatologists and their practitioners cost-effective, patient-centered care and expedited visits.

This island also had available a repertoire of highly sensitive and specific biomarker tests for diagnosing and providing prognosis for patients with RA, including tests for anti-agalactosyl IgG antibodies, matrix metalloproteinase- $3^{18}$, and others. This, too, promoted their personalized care. Data were entered, trended, and stored electronically, and were accessible to caregivers, physicians, rheumatologists, their staffs, and to patients and their families. Portable electronic devices were given to patients in the waiting areas to provide an uncomplicated, expedited way of obtaining accurate patient data and outcome measures ${ }^{19}$. Communication was carried out electronically in place of visits whenever possible. There was collaborative, team-based care among rheumatologists, orthopedists, physiatrists, allied health professionals, social workers, and PCP. Electronic health records were easily accessible to all, and they enhanced communication. The island community had enlightened and aggressive programs to eliminate medical "excess." For example, in rheumatology, considerable cost savings occurred from not ordering imaging and other studies for patients with back pain, from not ordering antinuclear antibody studies and other studies for patients with fibromyalgia and regional/soft-tissue pain syndromes, and from reducing expenditures on complementary and alternative medicine. Perhaps these initiatives helped fund their comprehensive arthritis care. Outcome data for the early arthritis population were very impressive. Care was available, accessible, economical, safe, patient-centered, efficient, equitable, effective, and of extremely high quality, just as has been advocated ${ }^{11}$.

Was it just a dream, I wondered?
“... life is moral responsibility. Life is several other things, we do not deny... but it is steadily and sturdily and always moral responsibility."

- Elizabeth Stuart Phelps

\section{DAVID KOVACS, MD, \\ Postdoctoral Fellow; \\ KARINA D. TORRALBA, $M D$,}

Assistant Professor,

Keck School of Medicine,

University of Southern California (USC),

Los Angeles, California;

DAVID A. FOX, MD,

Professor and Chief,

Division of Rheumatology, Department of Medicine,

University of Michigan School of Medicine,

Ann Arbor, Michigan;

DANIEL H. SOLOMON, MD, MPH,

Professor,

Brigham and Women's Hospital,

Harvard Medical School,

Boston, Massachusetts;

RICHARD S. PANUSH, MD, MACP, MACR,

Professor,

Division of Rheumatology, Department of Medicine,

Keck School of Medicine, USC, and LAC + USC Medical Center, Los Angeles, California, USA

Address correspondence to Dr. R. Panush, 2011 Zonal Ave., HMR 711, Keck School of Medicine, USC, Los Angeles, CA 90032, USA.

E-mail:panush@usc.edu

\section{REFERENCES}

1. Berwick DM. A piece of mind. To Isaiah. JAMA 2012;307:2597-9.

2. Tavares R, Pope J, Tremblay JL, Thorne J, Bykerk V, Lazovskis J, et al. Time to disease-modifying antirheumatic drug treatment in rheumatoid arthritis and its predictors: A national, multicenter, retrospective cohort. J Rheumatol 2012;39:2088-97.

3. Villeneuve E, Nam JL, Bell MJ, Deighton CM, Felson DT, Hazes $\mathrm{JM}$, et al. A systematic literature review of strategies promoting early referral and reducing delays in the diagnosis and management of inflammatory arthritis. Ann Rheum Dis 2012 Apr 24 (E-pub ahead of print)

4. Panush RS. Acute arthritis associated with febrile viral-like respiratory syndromes. J Rheumatol 1974;1:299-307.

5. Ortiz EC, Torralba KD, O’Dell JR, Panush RS. Later comes earlier, nowadays [editorial]. J Rheumatol 2011;38:2287-9.

6. Barton JI, Trupin L, Schillinger D, Gansky SA, Tonner C, Margaretten M, et al. Racial and ethnic disparities in disease activity and function among persons with RA with university-affiliated clinics. Arthritis Care Res 2011;63:1238-46.

7. Solomon DH, Ayanian JZ, Yelin E, Shaykevich T, Brookhart MA, Katz JN. Use of disease-modifying medications for RA by race and ethnicity in the national ambulatory medical care survey. Arthritis Care Res 2012;64:184-9.

8. Torralba KD, Panush RS, Quismorio FP Jr. Early arthritis: A race to the starting line. Rheum Dis Clin North Am 2012;38:xiii-xv.

9. Panush RS, Quismorio F, Fox DA. Epilogue: How will we care for patients with early arthritis? Rheum Dis Clin 2012;38:427-9.

10. Verstappen SM, Jacobs JW, van der Veen MJ, Heurkens AH, Schenk Y, ter Borg EJ, et al. Intensive treatment with methotrexate in early rheumatoid arthritis: Aiming for remission. Computer 
Assisted Management in Early Rheumatoid Arthritis (CAMERA, an open-label strategy trial). Ann Rheum Dis 2007;66:1443-9.

11. Committee on Quality of Healthcare in America, Institute of Medicine. Crossing the quality chasm: A new health system for the 21st century. Washington, DC: National Academy Press; 2001.

12. Panush RS. Rheumatology. In: Khardori NM, Barker J, Gersh BJ, LeRoith D, Panush RS, Talley NJ, et al. Year book of medicine 2012. Elsevier; 2012 [in press].

13. Townsend A, Adam P, Cox SM, Li LC. Everyday ethics and help-seeking in early rheumatoid arthritis. Chronic Illn 2010; 3:171-82.

14. Smolen JS, Landewe R, Breedveld FC, Dougados M, Emery P, Gaujoux-Viala C, et al. EULAR recommendations for the management of rheumatoid arthritis with synthetic and biological disease-modifying antirheumatic drugs. Ann Rheum Dis 2010;69:964-75.
15. Singh JA, Furst DE, Bharat A, Curtis JR, Kavanaugh AF, Kremer JM, et al. 2012 update of the 2008 American College of Rheumatology recommendations for the use of disease-modifying antirheumatic drugs and biologic agents in the treatment of rheumatoid arthritis. Arthritis Care Res 2012;64:625-39.

16. van Eijk-Hustings Y, van Tubergen A, Boström C, Braychenko E, Buss B, Felix J, et al. EULAR recommendations for the role of the nurse in the management of chronic inflammatory arthritis. Ann Rheum Dis 2012;71:13-9.

17. Gartner M, Fabrizii JP, Koban E, Holbik M, Machold LP, Smolen JS, et al. Immediate access rheumatology clinic: efficiency and outcomes. Ann Rheum Dis 2012;71:363-8.

18. Hayashi N, Nishimura K, Kumagai S. New biomarkers for rheumatoid arthritis. Rinsho Byori 2008;56:297-308.

19. Curtis JR. Personal communication, July 2012.

J Rheumatol 2012;39:2059-61; doi:10.3899/jrheum.121030 